\title{
THE UNIVERSITY STUDENTS' PERCEPTION OF CREATIVE WRITING IN RELATION WRITING SKILL
}

\author{
Gina Larasaty \\ Universitas Wiralodra \\ E-mail: Gina_larasaty@unwir.ac.id
}

\begin{abstract}
In this era, writing is one of the skills that should be mastered by the students, because it will be useful in the future. Writing has a purpose of entertaining and of giving the information, for example, in creative writing. This research aimed to know the students' perception of abilities they acquired after they participated in creative writing at the university level. The method of this research is descriptive analysis. The Participants of this research are coming from students in the fourth semester of English Department in Wiralodra University who took the Poetry subject Then the study resulted in the identification of abilities the students acquired after learning creative writing, the students are more self-confidence, critical reading and gain their vocabulary, grammar and punctuation in writing.
\end{abstract}

Keywords: Writing, Creative Writing, Students' Perspective

\begin{abstract}
Abstrak
Di era ini, menulis adalah salah satu keterampilan yang harus dikuasai oleh mahasiswa, karena akan berguna di masa depan. Menulis bertujuan untuk menghibur dan memberikan informasi. Misalnya dalam penulisan kreatif. Penelitian ini bertujuan untuk mengetahui persepsi mahasiswa tentang kemampuan yang mereka peroleh setelah mereka berpartisipasi dalam penulisan kreatif di tingkat Universitas. Metode penelitian ini adalah analisis deskriptif. Partisipan dalam penelitian ini berasal dari mahasiswa semester empat Jurusan Bahasa Inggris di Universitas Wiralodra yang mengambil Mata Kuliah Poety. Kemudian penelitian mengidentifikasi kemampuan yang diperoleh mahasiswa setelah belajar menulis kreatif, mereka lebih percaya diri, membaca kritis. dan mendapatkan kosakata, tata bahasa dan tanda baca mereka secara tertulis.
\end{abstract}

Kata Kunci: Menulis, Menulis Kreatif, Perspektif Mahasiswa

\section{INTRODUCTION}

Writing is one of the most important abilities and needs to be mastered by every student. In writing skills, students are expected to be able to express their ideas, thoughts and feelings in written form.

Nevertheless, in reality, many students have difficulty in expressing their ideas into written form; one of them is in terms of creative writing. Nowadays, creativity is one of the 
abilities that everyone must-have. Graham and Hebert (2010: 3) said that "globalization and technological development have changed the world of work today where reading and writing are critical capabilities in the world of work today. Creative writing is an essential ability in the world of work today, such as: writing a script or scenario, editor, writing a book, copywriter, blogger and journalist.

According to the national writers association in the field of education (UK), creative writing can be defined as follows: Creative writing is the study of writing (including poetry, fiction, drama, and non-fiction creative) and its context through creative production and reflection on the process. By writing, one is not always writing a book, but also a performance script, poetry script, and others. Creative writing can use any form or genre of writing as an exemplary subject of study, but the production of creative writing tends not to be in the form of information but an imaginative interpretation. (Bennett, Clarke, Motion, and Naidoo, 2008).
Students are expected to be able to develop their ideas and improve their ability to write, not only in writing books or information, but creative writing can also improve their ability to develop ideas and ideas in the form of writing with various genres of writing such as writing scripts, writing poems, writing short stories and others. The forms of creative writing can be fictitious or written and not something that aims to provide information which forms of creative writing are subjective and concise.

According to Widyamartaya (1984), writing is a forum for pouring what is thought into an article. Writing is a process of thinking human activity that wants to use the soul's content to others or themselves in their writings. In the process of writing, it is subjective in that the form of creative writing is fiction and does not contain accurate information, in writing creative writing students use their imagination and spill it into writing in the genre they want. Writing can be interpreted as a whole series of activities for someone to express 
ideas and convey them through written language to the reader to be understood as intended by the author or author (Mundziroh et al., 2013). Writing is a process to express ideas or ideas that are packaged and delivered in linguistic elements consisting of words, sentences, and paragraphs and in written form.

The purpose of This research is to determine students' perceptions of abilities they acquired after they participated in creative writing.Therefore we are interested in researching or developing studies on creative writing, with the following problem formulation: “ What is the primary skill that students perceive after they learned creative writing? In this study, we hope that it will have benefits for students to be more creative and be able to develop their ideas and creativity in their particular written form.

\section{METHOD}

The method used in this research is a qualitative method using descriptive analysis. This data was obtained from fourth-semester students studying at Wiralodra University, Indramayu, who took the "Poetry" course in the English Language Study Program. To answer the purpose of this research, we use questionnaire and interview instruments. Where this instrument will dig up information about their perceptions of abilities in writing skill, they acquired after they participated in creative writing. Creative writing activities focused only on writing poetry. The questionnaire used consisted of 7 points describing their perceptions about the impact of creative writing, then interviews to explore more information obtained from the questionnaire.

\section{FINDINGS AND DISCUSSION}

To obtain information about students' perceptions of creative writing at the student level, we gave several questions in the form of questionnaires to all study participants and conducted interviews to support this research data. The following table is the percentage of questionnaire data. 
Table. 1. Students Perception of Creative Writing

\begin{tabular}{|ll|c|c|c|c|}
\hline \multicolumn{1}{|c|}{$\begin{array}{c}\text { Creative writing has a positive } \\
\text { impact on: }\end{array}$} & $\begin{array}{c}\text { S. Agree } \\
\mathbf{( 4 )}\end{array}$ & $\begin{array}{c}\text { Agree } \\
\mathbf{( 3 )}\end{array}$ & $\begin{array}{c}\text { Disagree } \\
\mathbf{( 2 )}\end{array}$ & $\begin{array}{c}\text { S. Disagree } \\
(\mathbf{1})\end{array}$ \\
\hline 1. & Confidence in writing & $5(21.7 \%)$ & $18(78.3 \%)$ & - & - \\
\hline 2. & $\begin{array}{l}\text { Comfort with others viewing own } \\
\text { writing }\end{array}$ & $1(4.3 \%)$ & $19(82.6 \%)$ & $3(13.1 \%)$ & - \\
\hline 3. & Grammar and punctuation skills & $12(52.2 \%)$ & $10(43.5 \%)$ & $1(4.3 \%)$ & - \\
\hline 4. & Formal essay writing skills & $4(17.4 \%)$ & $16(69.5 \%)$ & $3(13.1 \%)$ & - \\
\hline 5. & Critical reading of the literature & $5(21.7 \%)$ & $17(73.9 \%)$ & $1(4.3 \%)$ & - \\
\hline 6. & Vocabulary and form & $12(52.2 \%)$ & $10(43.5 \%)$ & $1(4.3 \%)$ & - \\
\hline 7. & Expressiveness of writings & $12(52.2 \%)$ & $11(47.8 \%)$ & - & - \\
\hline
\end{tabular}

(Adopted from Dr Kathleen Bell, De Montfort University, Leicester)

In this analysis, the writer used the frequency scale in interpreting the data above. Based on the above data, it can be concluded based on the frequency scale that the Likert scale can be drawn concerning agree and disagree - so based on the number or percentage of answers that students have a positive impact in creative writing activities. Moreover, these positive effects are felt by many students regarding expressions in writing and are followed by several other skills, as about selfconfidence, critical reading, vocabulary, grammar and punctuation.

\section{Confidence in Writing}

Based on the questionnaire, we found that the majority of students answered agree when asked about the matter of confidence in writing. This is evidenced by the number of percentages in statement number 1 , where $78.3 \%$ of students answered agree, and $21.7 \%$ of students answered strongly agree. This can be interpreted that after learning to write creative students become more confident in writing because they become accustomed to using vocabulary that can support their writing itself. This is supported by the results of our interview with one of the study participants who stated that "I am more confident because I can choose the appropriate vocabulary."

Based on the above statement, we can conclude that creative writing has a positive impact on students, such as the accuracy in using appropriate vocabulary. The selection of vocabulary in writing is 
the most crucial thing for students. They can express their ideas or feelings through creative writing with the right vocabulary and following the essay they want to make. Then other students also added their perceptions as follows,

"Yes, I am confident because I feel I have understood the stages of writing and understood the theory."

In addition to the accuracy of vocabulary that can support confidence in writing, it turns out that understanding or mastery of writing theory and stages in writing can also make students confident in writing something. However, stages and theories of writing will not develop if one has never practised writing. Because if only mastering the theory but not practised, the theory will not bring more considerable influence on someone. So it can be concluded that when students practice writing a lot, especially creative writing, understanding the theory and stages of writing will follow automatically, as well as creativity in writing that can be increased unconsciously.

\section{Comfortable When Showing or}

\section{Posts to Others}

Students feel confident in writing after learning to write creatively; they will be comfortable when others see their writing. This is evidenced by the many 19 students who claimed to agree and one student who claimed to agree with this second statement strongly. However, not all students claim that there are also students who disagree with this statement. There were 3 out of 23 students who answered disagreed or uncomfortable when others see their writing. As additional information, we explore information related to factors that cause them to agree and disagree with the second statement in this research questionnaire. According to one of the speakers conveyed their agreement as follows,

"It is comfortable; I mean, that is my work. It is like a pride of my own because I made it myself without copas or whatsoever."

Producing works in writing is indeed something to be proud of. Confidence, when others see our work, is also vital. As in the statement of the resource person 
above, he was proud when he poured his ideas and creativity that can be seen by others. Because he believes that the writing he made is purely his own, and it could be that his writing can motivate readers or others. But self-confidence is not always shared by everyone; there are also many writers who still feel uncomfortable when others see their writing for several reasons. For example, feel the sentence used is not continuous with other sentences, the writing is not good or less interesting, as conveyed by one of the three speakers who stated that they disagree or are uncomfortable if others see their writing, he stated

"No, shame. Afraid of many being wrongly kept laughing if the reception is wrong, the grammar is wrong. So lack confidence if writing is seen by friends. "

Writing skills are indeed essential to make a creative paper. Based on the statement above, the resource person is not confident in his abilities. Though everyone has their skills, it is just that many exercises determine the quality of the writing itself. It is like someone who has a lot of creative ideas but is not written down in the same writing cannot write. Because the ability to write can be practiced. Therefore, practice in creative writing is essential to practice the writing ability itself.

\section{Grammar and Punctuation} Ability

More than half of the students, $52.2 \%$ felt strongly agree that creative writing can improve their grammar and punctuation skills, and $43 \%$ of them also expressed their agreement. That is because now they have become more aware of the correct use of grammar after they have taken poetry courses. Moreover, grammar in English is more complicated compared to grammar in Indonesian. The role of the lecturer is crucial in helping students identify mistakes in their writing.

"Yes, I didn't miss a lot of things, I kept saying this was wrong, so I kept getting it like that."

By knowing things that are not right in their writing, it can motivate students to improve their abilities and then improve their writing to be better. Creative writing also helps improve their 
understanding of the correct use of punctuation.

"so I know better, oh this is the perfect grammar or not ".

They found out How to write the dot, oh this is like a coma. Students also confess by writing creatively, making them now more aware and aware if there is an error or something that is not right in their writing. Moreover, the use of punctuation is also essential because it can affect the meaning of a context. While only $4.3 \%$ of students feel disagree with the statement.

\section{The Ability to Write Formal}

\section{Essays}

Writing habits are beneficial to improve our writing skills, both in the ability to write fiction or nonfiction writing. In creative writing activities, one can be the containers for us to express what is in our minds and what we are feeling. Also, creative writing activities can have a positive influence, such as in terms of grammar, use of punctuation, and adding new vocabulary so that it can also help us in writing different genres. This is evidenced by $69.5 \%$ of participants who agreed that
Creative writing activities could also influence the ability to write more formal writing such as writing essays, journals, papers, and so forth. This data was also supported by one of the participant interviews.

"Yes, Because we learn grammar too, from grammar, we add vocab. It automatically goes to the journal too, oh yeah there are additions."

In addition to influencing the ability to write formal writing, creative writing can also help us to have many creative ideas, which can be very useful so that our writing does not look dull and makes it easy for us to convey ideas.

"So there are rich ... new inspiration also. Oh, yeah, yes, I got more innovative and creative ideas. So we can put it. More impression. "

\section{The ability to critical reading}

Based on the data we obtained from the questionnaire, 23 students we examined about creative writing. They have different opinions, and 17 of them choose to agree that their ability when criticizing a reading or text they agree that their abilities increase after they get the opportunity to write 
creatively in the "Poetry" course. The percentage of students who chose to agree that they were critical when reading a literary work was $73.9 \%$.

Besides, we conducted the questionnaire; we also conducted interviews to support the data, apart from the questionnaire data. The data we obtained from the interview took the form of a recording. From the interview data, we obtained many statements stating that many students chose to agree with their ability to criticize work or writing. At this point, we ask "if after you learn creative writing, you are critical when reading a work such as poetry or a novel and then you criticize it?" then one of the students gave a statement that

"It's critical, just for me, it's rich, for me it's lacking, but for him it's perfect, so I also still need a lot to learn. This should be how critical it is not revealed but critical, it's ${ }^{6}$ oh how come it's like this '."

So one of the students we gave questionnaires and interviews with, most of them chose to agree because they only criticized the readings they read only silently or not disclosed. As quoted in the statement above, he mentioned that only criticize in the heart alone. But some of the students we gave interviews gave a statement that

"Yeah, sometimes sometimes, it becomes a material for discussions with friends like dissecting what novels are like that, so this together like this"

There are many choices when criticizing a literary work based on their desire to share with friends or discuss with friends, or they want to criticize it in their hearts. Here, it can be seen that by critiquing a text or reading literature by indirectly their ability to think critically increases if they are consistent in reading a text that can support them towards critical thinking — especially reading literary works that correlate with creative writing.

Some of them also chose to strongly agree that their critical thinking ability when reading or text increased, five students chose to agree strongly. The percentage for students who choose strongly agrees to be $21.7 \%$. Some choose not to agree on the point that they can criticize a reading or literary work that is as much as one person. The 
percentage of students who chose to disagree was only $4.3 \%$.

So it can be concluded that the ability to criticize a reading is needed, in order to obtain information about the literary work they can also develop their critical thinking skills not only in reading a text but also when they want to write a text which later before writing the text the student will think back before writing it in a book.

\section{Vocabulary and Format}

Vocabulary is essential when someone wants to write a reading or worktext. Because to write work requires much supporting vocabulary. Furthermore, from the data we obtained when conducting questionnaires and interviews, most of them chose to agree strongly and disagree in terms of vocabulary and format because most of them think that when they get a chance to write exceptionally creative writing, their vocabulary and class of words will increase. Because when writing, especially creative writing, students are required to write creatively and imaginatively. Therefore, indirectly they get much new vocabulary, and they will get more knowledge about a class of words - word classes like; adjectives, verbs, conjunctions and others.

By creative writing, it is hoped that they can increase their creativity in developing their ideas and ideas, especially in writing. Moreover, increase their imagination in thinking more creatively and spilling it into writing.

Data for vocabulary points and formats, which are 12 students choosing to strongly agree with creative writing can improve vocabulary and format (word class). The percentage is $52.2 \%$, they chose to strongly agree because they believe that by writing in addition to getting new information, criticizing the reading but they can also add new vocabulary and format (word classes) when writing. That way, their abilities will increase when they consistently write creatively and read literary texts. As for those who chose to agree, there were ten students, with a percentage of $43.5 \%$. Moreover, the last one is students who choose not to agree with one person with a percentage of $4.3 \%$. 


\section{Expressive in writing}

Based on data from the questionnaire, as many as $52.2 \%$ of students expressed strongly agree, and $47.8 \%$ stated agreed that creative writing makes them more expansive in expressing their feelings in written form. This is very reasonable because creative writing can be a means for them to express themselves, convey ideas, and express their feelings.

"He'em he'em, now yes. For example, rich again often write so upset, confide so. Create a diary"

By taking poetry classes and learning about creative writing, participants can find fun ways for them to express themselves. Both the form of writing in the form of diary, poetry or other things. Likewise, when they have ideas, they too can immediately put it in writing

"Sometimes, if there is an idea, it is better to write it right away. You don't have to publish it, but yes I write "

Based on the results of questionnaires and interviews, it can be concluded that creative writing activities have a positive impact on their ability in English, especially writing skills. By the opinion of Ken Hylan (2002), which states that the main focus in creative writing is in expressing themselves.

\section{CONCLUSION}

According to the data from the questionnaire and the interview, we conclude that the activity in creative writing has a good impact on their skill in English, particularly in writing. According to Ken Hylan (2002) states that "the focus in creative writing is expressing the idea". Mostly, the participants agree with the point about creative writing. not only expressiveness of writings but the good impact are they could increase several skills such as; their confidence, critical reading, vocabulary, grammar and punctuation.

The Students' perceptions of creative writing at the University level, we as writers concluded that students who took the "Poetry" course were more expressive in writing. This means that they are freer to express or express their creative ideas through the writings they make. Almost all students who 
participated in this study gave favourable responses about creative writing through the interviews we conducted and the questionnaire data that we analyzed. Not only expressive in writing, but other positive impacts obtained by students are the increase in several other skills, such as self-confidence, critical reading, vocabulary, grammar and punctuation. Thus, it is expected that creative writing skills among students can continue to increase and become better trained after taking the course "Poetry" in the Department of English Education, Wiralodra University, Indramayu

\section{REFERENCES}

Bennett, A., Clarke, G., Motion.,\& Naidoo, B. (2008). Creative writing subject benchmark statement.URL: http://www.nawe.co.uk/writin g-in-education/writing-atuniversity/research.html. Accessed on 17 December 2019.
Graham and Hebret (2010). Writing to Read: Evidence How for Writing can Improve reading. New York. Carnegie Corporation.

Hyland, K. (2002). Teaching and Researching Writing. Harlow: Longman.

Mundziroh, S., Andayani, \& Saddhono, K. (2013).

Peningkatan Kemampuan Menulis CeritaDengan Menggunakan Metode Picture And Picture Pada Siswa Sekolah Dasar.BASASTRA Jurnal Penelitian Bahasa, Sastra Indonesia Dan Pengajarannya, 2(April),110.

Widyamartaya, A. (1984). Kreatif Mengarang. Yogyakarta: Yayasan Kanisius. 